DOI: $10.2478 / \mathrm{v} 10025-007-0009-3$

JOURNAL OF WATER

AND LAND DEVELOPMENT

J. Water Land Dev. No. 10, 2006: 107-120

\title{
Change in the number of ponds in the Wyskoć catchment basin in the years 1980-2003 and characteristics of the newly excavated ponds
}

\author{
Radosław JUSZCZAK ${ }^{1)}$, Andrzej KĘDZIORA ${ }^{2)}$, \\ Jacek LEŚSNY ${ }^{1}$, Janusz OLEJNIK ${ }^{1)}$
}

1) Agrometeorology Department, A. Cieszkowski Agricultural University of Poznań ul. Piątkowska 94b, 60-691 Poznań, Poland

2) Research Centre for Agricultural and Forest Environment, Polish Academy of Science, ul. Bukowska 19, 60-809 Poznań, Poland

\begin{abstract}
The article presents the results of analyses of changes in the number of ponds in the Wyskoć catchment basin carried out in the years 1980-2003 and the characteristics of ponds excavated in that period. Only water reservoirs of an area less than 2 ha were considered. Analyses were based on topographic maps in the scale of 1:10 000 and aerial photographs taken in 1996. The results indicated that the number of filled ponds increased, especially those located in fields and grasslands. However, forest and wetland ponds were the most resistant to the processes of quantitative degradation because not even a single pond was filled during the analysed period. Over $70 \%$ newly excavated water bodies were made as an effect of exploitation of mineral and peat resources. However, nowadays ponds are more often created as a result of intentional human activities and are used for fish farming, recreation and as water retention reservoirs used in irrigation of small agricultural and gardening areas.
\end{abstract}

Key words: small ponds, changes in pond number, human impact

\section{INTRODUCTION}

Small surface water reservoirs constitute a valuable element of the landscape. They positively influence the level of ground water, soil moisture and the microclimate of the nearby terrain (HUBBARD and LINDER, 1986; FIEDLER and SZAFRAŃSKI, 1999; FIEDLER et. al., 2002; KOSTURKIEWICZ and FIEDLER, 1995; 1996; KOSTURKIEWICZ et al., 2001; 2002; SMITH et. al., 2002). They effectively increase the biodiversity of flora and fauna gathering much more rare species than other aquatic ecosystems (BIGGS et. al., 2000; BRIERS and BIGGS, 2003; NICOLET, 2000; OERTLI et. al., 2002; WILLIAMS et al., 1998; 2004). Being biogeochemical barriers, small ponds, clean groundwater from the area contamination which is carried by 
them (ŻYCZYŃSKA-BAŁONIAK et. al., 1990; RYSZKOWSKI and ŻYCZYŃSKA-BAŁONIAK, 1998; FLEISCHER et. al., 1994; GUSTAFSON et. al., 1998; 2000; KOSKIAHO et. al., 2003). Moreover, they increase the aesthetic value of the landscape and have many economic and recreational applications which increasingly determine the practical importance of water ecosystems (JUSZCZAK, 2004). Despite having many positive functions, these water bodies are now under a strong human impact (JUSZCZAK, 2002; JUSZCZAK and KĘDZIORA, 2003). The consequence of such pressure is a decrease of their natural value and, very often, a complete degradation which eventually leads to their disappearance.

Ponds undergo qualitative and quantitative degradation on the area of the whole Europe. It is estimated that in the north-western European countries, losses of ponds number to $40-90 \%$ (depending on the region) (HULL, 1997). In the Great Britain, for instance, losses of ponds have been estimated for $38 \%$, since the end of the Second World War (SWAN and OLDHAM, 1989). The average rate of disappearance of ponds in that country has been estimated as 1\% per year (WILLIAMS et. al., 1998; 1999; BIGGS et. al., 2000; NICOLET, 2000). In the same period, in Denmark only 12331 lakes and ponds remained out of the initial number of 16854 (i.e. 73\%) (BÜLOW-OLSEN, 1988). Significant loss of ponds is also observed in Germany and Italy (BISCHOFF and JONGMAN, 1993). According to KALETTKA (1996), in the north of Germany the number of ponds has decreased from $28 \%$ to even $88 \%$, depending on the region, since the end of the Second World War.

Similar tendency is observed in Poland. In 1941 only 4873 ponds were left in the Wielkopolska Lowland, out of 11068 present at the beginning of the 1890s, whereas only 2490 survived until the 1960 s which is only $22 \%$ (KANIECKI, 1991). Numerous dams in the watercourse which were built in order to drive small mills were almost completely degraded. On the basis of available maps and records from the 18th century, GOEASKI (1988) established that in 1790 there were 1208 water mills in the area of $15000 \mathrm{~km}^{2}$ from which only 70 (i.e. merely $6 \%$ ) survived till 1960. PIEŃKOWSKI (2000) claims that, at present, in the Myśliborskie Lakeland only 1686 ponds, with the area smaller than 1 ha, were left out of 5442 (i.e. 31\%) which were marked on the maps from the end of the 19th century.

The ponds can disappear for many reasons of natural or anthropogenic character. Among the natural ones the following are usually mentioned: natural succession and sedimentation of mineral and organic matter (KEEN, 2000; NICOLET, 2000), as well as susceptibility of such water bodies (particularly seasonal ones) to running dry in dry periods (KOSTURKIEWICZ and FIEDLER, 1995; 1996; WILLIAMS et. al., 2000). However, in recent years the processes of anthropogenic nature have been pointed out as the main reason of disappearance of water bodies. Qualitative and quantitative degradation of ponds is, first of all, a consequence of intense agricultural development (NICOLET, 2000; PIEŃKOWSKI, 2000; RINGLERA, 1976; RYSZKOWSKI et. al., 1996; WILLIAMS et. al., 1999; 2000) and urban sprawl (COL- 
LINSON et. al., 1995; OLDHAM and SWAN, 1997), which have exerted particularly great pressure on natural environment after the Second World War.

Despite disappearing of ponds, a great emphasis is placed on the fact that the number of such water bodies in many countries of the world is increasing. In the USA, for instance, it is estimated that the rate of growth of ponds may amount even to $3 \%$ annually (SMITH et al., 2002). Thereby, it is necessary to consider if quantitative disappearance of ponds is a one-way process? Perhaps, despite ongoing degradation of ponds, the interest in these elements of the hydrographic network is (or will be) big enough to reverse the process? In order to answer these questions properly, it is important to consider why ponds disappear and how that process can and must be reversed.

The article presents the results of analyses carried out in the years 1980-2003 of changes in the number of ponds of the Wyskoć catchment and the characteristics of the ponds excavated in that period.

\section{MATERIAL AND METHODS}

\section{STUDIED AREA}

The study catchment is located about $50 \mathrm{~km}$ south of Poznań (south part of Wielkopolska Region) in Leszczyńskie Lake District in Poland. Geomorphologically, this region is dominated by a flat or rolling ground moraine (KONDRACKI, 1998).

The catchment area equals to $182.5 \mathrm{~km}^{2}$. Owing to significant differences in land use structure and geomorphology of the catchment area, this watershed was divided into two parts known as Turew Region and Dolsk Region (Fig. 1).

Fig. 1. Location of the Wyskoć catchment area

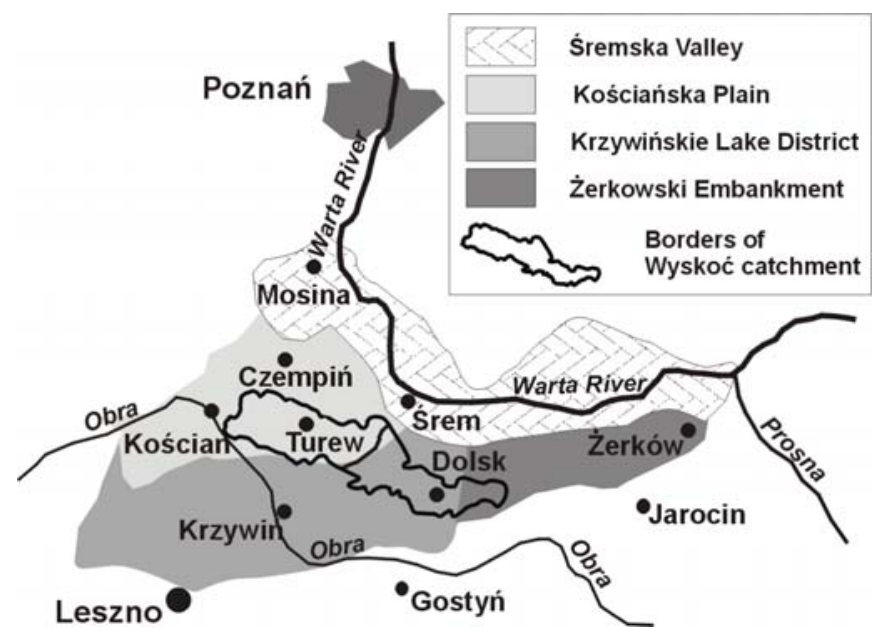


The Turew Region (western part of the catchment) is a typically rural area, which besides a considerable share of arable lands is characterized by a lack of lakes. This region is part of the flat Kościan Plain and its area is $101.4 \mathrm{~km}^{2}$. The Dolsk Region (eastern part of the catchment) occupies the area of $81.1 \mathrm{~km}^{2}$ and is characterized by a big share of forests, lakes and wetlands, in relation to relatively small area occupied by arable lands. This region occupies a very small part of the Kościan Plain (north-west part of the catchment) and part of the Krzywińskie Lake District and the Żerkowskie Embankment. A dominant form of land configuration is a rolling ground moraine which has many local non-outflow hollows including terminal moraines and eskers (KONDRACKI, 1998).

\section{METHODS}

Analyses of the changes in the number of ponds within the Wyskoc catchment were based on topographic maps (scale of 1:10 000) as well as on aerial photographs from 1996. The number and location of ponds was then verified during field study conducted in the years 2001-2003. The number of ponds on the maps from 1975-1987 (dates of preparation of topographic maps; scale of 1:10 000) was compared with the actual number of ponds present in the studied area.

Since the topographic preparation of the maps lasted several years (at the turn of the 1970s and 1980s), it was accepted that the maps presented the number of ponds for 1980. Thus, changes in the ponds number were established for the period of 24 years, from 1980 to 2003 .

Only the ponds of the area smaller than 2 ha were taken into account during the analyses, since only such water bodies are recognised as 'small', according to the classification of water reservoirs applied in the Great Britain (COLLINSON et al., 1995; BIGGS et al., 1998; 2000; WILliAMS et al., 1999; 2004). Several types of ponds were characterized, such as: midfield ponds, forest ponds, grassland ponds, wetland ponds and farmstead ponds (located directly near buildings) (JUSZCZAK, 2004). Each water body could be classified to one of the above types depending on the type of land dominating the area surrounding the pond. If many types of land occurred near the pond, it was classified to one of the above groups depending on which type of land use exerted most unfavourable human impact on the value of the pond. It was assumed that human impact would be smallest in wetlands, then in forests and grasslands and the biggest it would be in the agricultural and built-up areas. For example, if the forest constituted $34 \%$ of land around the pond, $33 \%$ was occupied by wetland and $33 \%$ by cultivated field, then the pond was classified as a midfield pond.

Ponds were analysed regarding their surface, shape, morphology, relief of its surrounding, intermittence of water in the pond, hydrography and the type of adjoining land. 


\section{RESULTS}

Altogether 641 of water bodies (with the area smaller than 2 ha) were inventoried in the Wyskoć catchment. These ponds occupied the surface of 129 ha and their average density was estimated at 3.5 per $\mathrm{km}^{2}$. The most numerous were wetland ponds (212 water bodies) and grassland ponds (163). Midfield ponds made up 110 , and farmstead ponds 81 . The least numerous were forest ponds (75).

In the years 1980-2003 27 ponds smaller than 2 ha were filled-in in the Wyskoć catchment (i.e. $4.2 \%$ of the present number of ponds in the analysed area) (Tab. 1). The biggest loss of the ponds was observed among those located in the grassland. Also several midfield and farmstead reservoirs were filled. Such changes were not observed among wetland and forest ponds. In the whole area, 13 grassland ponds (i.e. $2 \%$ of the ponds in the catchment), 8 farmstead ponds (i.e. $1.2 \%$ ) and 6 midfield ponds (i.e. $0.9 \%$ ) were filled. If we compare these figures with the number of ponds of particular type present in the catchment now, it turns

Table 1. The ponds excavated and filled in the years 1980-2003 in the Wyskoć catchment

\begin{tabular}{|c|c|c|c|c|c|}
\hline Types of ponds & $\begin{array}{l}\text { Ponds present } \\
\text { in the catch- } \\
\text { ment now }\end{array}$ & $\begin{array}{r}\text { Ponds wh } \\
\text { changed } \\
20\end{array}$ & $\begin{array}{l}\text { number } \\
1980-\end{array}$ & $\begin{array}{l}\% \text { of ponds in the } \\
\text { Wyskoć catch- } \\
\text { ment } 641=100 \%\end{array}$ & $\begin{array}{l}\% \text { of ponds } \\
\text { of a given } \\
\text { type }\end{array}$ \\
\hline Midfield ponds & 110 & \multirow{6}{*}{$\stackrel{\text { 导 }}{\stackrel{\vec{I}}{=}}$} & 6 & 0.9 & 5.5 \\
\hline Grassland ponds & 163 & & 13 & 2.0 & 8.0 \\
\hline Wetland ponds & 212 & & 0 & 0.0 & 0.0 \\
\hline Forest ponds & 75 & & 0 & 0.0 & 0.0 \\
\hline Farmstead ponds & 81 & & 8 & 1.2 & 9.9 \\
\hline In total & 641 & & 27 & 4.2 & \\
\hline Midfield ponds & 110 & \multirow{6}{*}{ 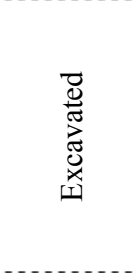 } & 38 & 5.9 & 34.5 \\
\hline Grassland ponds & 163 & & 45 & 7.0 & 27.6 \\
\hline Wetland ponds & 212 & & 20 & 3.1 & 9.4 \\
\hline Forest ponds & 75 & & 12 & 1.9 & 16.0 \\
\hline Farmstead ponds & 81 & & 17 & 2.7 & 21.0 \\
\hline In total & 641 & & 132 & 20.6 & \\
\hline Midfield ponds & 110 & \multirow{6}{*}{ 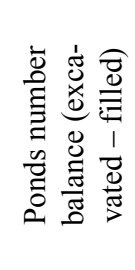 } & 32 & 5.0 & 29.1 \\
\hline Grassland ponds & 163 & & 32 & 5.0 & 19.6 \\
\hline Wetland ponds & 212 & & 20 & 3.1 & 9.4 \\
\hline Forest ponds & 75 & & 12 & 1.9 & 16.0 \\
\hline Farmstead ponds & 81 & & 9 & 1.4 & 11.1 \\
\hline In total & 641. & & 105 & 16.4 & \\
\hline $\begin{array}{l}\text { Average annual increment } \\
\text { of the number of ponds } \\
\text { from } 1980 \text { to } 2003\end{array}$ & & & 4.6 & $0.71 \%$ & \\
\hline
\end{tabular}


out that the biggest loss took place in the case of farmstead ponds $(9.9 \%)$, and not grassland ponds $(8 \%)$. The number of midfield ponds decreased by $5.5 \%$ of the present number of water bodies of this type.

However, during the same period, as many as 132 new water bodies were excavated, which constitutes as much as $20.6 \%$ of ponds smaller than 2 ha present in the catchment now. Most of the new ponds were excavated in the area of farmland and grassland $(5.9 \%$ and $7 \%$ of ponds present in the catchment respectively). Newly excavated wetland ponds constitute $3.1 \%$ of water bodies present in the catchment now, whereas farmstead ponds constitute $2.7 \%$ and forest ponds $1.9 \%$. In percentage terms, the number of midfield ponds has increased most among the excavated ponds (by $34.5 \%$ of the present ponds of this type), slightly smaller was percentage of grassland and farmstead ponds (27.6\% and $21.0 \%$ respectively). Relatively few ponds were excavated in the wetland area. They constitute merely $9.4 \%$ of the ponds of this type present in the catchment now.

When analysing the changes of the number of ponds in the given area, it is important to consider the balance of filled and excavated ponds in the past. It turns out that in the years 1980-2003 the number of ponds in the Wyskoc catchment increased by as many as 105 (i.e. by $16.4 \%$ in relation to the number of ponds present in the catchment now). Considering all ponds of the catchment, the biggest increase was observed regarding midfield and grassland ponds, by 5\%. The number of wetland ponds increased by $3.1 \%$ and the number of forest ponds by $1.9 \%$. The increase of farmstead ponds number is the lowest and makes up $1.4 \%$. However, after relating these figures to the number of different types of existing water bodies, it turns out that the biggest increase occurred among midfield ponds (by $29.1 \%$ in comparison to all ponds of this type), a little smaller increase took place in the case of grassland ponds (by 19.6\%), forest ponds (16.0\%) and farmstead ponds $(11.1 \%)$. The smallest increase occurred among wetland ponds (merely by $9.4 \%$ ). In the case of each of the analysed types of ponds a significant increase in the number was observed, at the level of $9 \%$ to $29 \%$, which may reflect positive trend in the changes of the number of ponds in the Wyskoc catchment. Average annual increment of ponds is 4.6 , which constitutes $0.71 \%$ of the number of ponds present in the catchment now.

Total area of the newly excavated ponds is 15.8 ha (Tab. 2); 5.4 ha are occupied by midfield ponds, 3.7 ha by grassland ponds, 2.6 ha by wetland ponds, 2.5 ha by forest ponds and 1.6 ha by farmstead ponds. Mean area of the newly excavated ponds is $1195 \mathrm{~m}^{2}$. Among the analysed water bodies, the largest are forest ponds $\left(2043 \mathrm{~m}^{2}\right)$ followed by midfield ponds $\left(1409 \mathrm{~m}^{2}\right)$ and wetland ponds $\left(1302 \mathrm{~m}^{2}\right)$, whereas the smallest are grassland $\left(826 \mathrm{~m}^{2}\right)$ and farmstead ponds $\left(968 \mathrm{~m}^{2}\right)$.

81 ponds created in the Wyskoć catchment after 1980 are not larger than 400 $\mathrm{m}^{2}$. Among 132 ponds analysed as many as 112 (above $82 \%$ ) have the area not larger than $2000 \mathrm{~m}^{2}$. Only 2 ponds (one midfield pond and one wetland pond) were 
Table 2. Detailed characteristics of ponds excavated in 1980-2003 in the Wyskoć catchment

\begin{tabular}{|c|c|c|c|c|c|c|c|c|}
\hline Inventory criteria of ponds & Detailed characteristics & 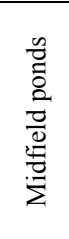 & 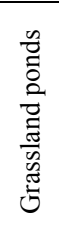 & 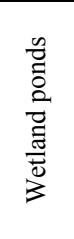 & 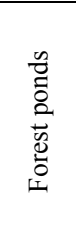 & 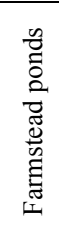 & 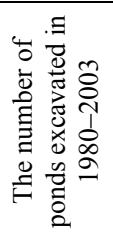 & 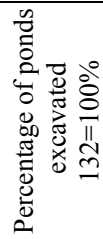 \\
\hline \multicolumn{2}{|l|}{ Number of ponds } & 38 & 45 & 20 & 12 & 17 & 132 & \\
\hline \multirow[t]{6}{*}{ Area of ponds, ha } & $>0.01$ & 7 & 8 & 3 & 4 & 5 & 27 & 20.5 \\
\hline & $0.011-0.04$ & 18 & 19 & 9 & 2 & 6 & 54 & 40.9 \\
\hline & $0.041-0.2$ & 8 & 12 & 6 & 3 & 2 & 31 & 23.5 \\
\hline & $0.21-0.6$ & 1 & 6 & 0 & 1 & 4 & 12 & 9.1 \\
\hline & $0.61-1.0$ & 3 & 0 & 1 & 2 & 0 & 6 & 4.5 \\
\hline & $>1.0$ & 1 & 0 & 1 & 0 & 0 & 2 & 1.5 \\
\hline \multicolumn{2}{|l|}{ Total area of ponds, ha } & 5.4 & 3.7 & 2.6 & 2.5 & 1.6 & 15.8 & \\
\hline \multicolumn{2}{|l|}{ Average area of ponds, $\mathrm{m}^{2}$} & 1409 & 826 & 1302 & 2043 & 968 & 1195 & \\
\hline \multirow[t]{2}{*}{ Shape of ponds } & round, oval, kidney shaped & 10 & 13 & 3 & 7 & 7 & 40 & 30.3 \\
\hline & square, rectangular, irregular & 28 & 32 & 17 & 5 & 10 & 92 & 69.7 \\
\hline Morphology & flat area & 6 & 0 & 0 & 3 & 3 & 12 & 9.1 \\
\hline \multirow[t]{2}{*}{ Location in relief } & depression $<1 \mathrm{~m}$ & 8 & 17 & 6 & 4 & 4 & 39 & 29.5 \\
\hline & depression $>1 \mathrm{~m}$ & 24 & 28 & 14 & 5 & 10 & 81 & 61.4 \\
\hline \multirow[t]{3}{*}{ Periodicity of occurrence } & no water & 5 & 2 & 0 & 2 & 2 & 11 & 8.3 \\
\hline & temporal & 7 & 10 & 5 & 6 & 2 & 30 & 22.7 \\
\hline & permanent & 26 & 33 & 15 & 4 & 13 & 91 & 68.9 \\
\hline \multirow{4}{*}{ 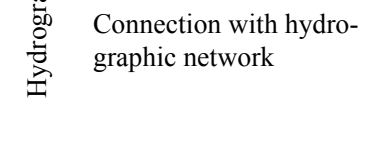 } & no connection & 33 & 37 & 15 & 9 & 15 & 109 & 82.6 \\
\hline & inlet & 4 & 4 & 4 & 0 & 1 & 13 & 9.8 \\
\hline & outflow & 0 & 2 & 0 & 0 & 0 & 2 & 1.5 \\
\hline & inlet and outflow & 1 & 2 & 1 & 3 & 1 & 8 & 6.1 \\
\hline \multicolumn{2}{|l|}{ Excavation of gravel, sand or clay } & 11 & 5 & 3 & 3 & 3 & 25 & 18.9 \\
\hline \multicolumn{2}{|l|}{ Peat ditches } & 13 & 30 & 16 & 2 & 3 & 64 & 48.5 \\
\hline
\end{tabular}


larger than 1 ha. It means that newly created ponds are small ones and their areas are usually not larger than 0.2 ha.

The shapes of the analysed ponds often (in 70\% of cases) reflected the anthropogenic character of the water bodies (they were square, rectangular or irregular). A little more than $30 \%$ of the ponds were round, oval or kidney shaped - which is typical for ponds of natural origin (JUSZCZAK, 2004).

It should be emphasised that more than $90 \%$ of newly created ponds were located in local hollows, $61 \%$ of which were in the hollows deeper than $1 \mathrm{~m}$. Only 6 midfield ponds, 3 forest ponds and 3 farmstead ponds were located in the "flat" area. Location of most of the ponds in the hollows significantly determines their retention features and assures longer durability of the water level than in the ponds located in a flat area.

Locations naturally predisposed for water retention were used when building new ponds, assuming they would not dry out. For most such ponds located in local hollows these assumptions were correct. However, as many as $8.3 \%$ of excavated ponds were dry during the inventory works. Most of them were located in flat area. Dry ponds occurred most often among midfield ponds (5) as well as grassland, forest and farmstead ponds ( 2 in each type). The ponds created in wetlands and marshlands appeared most durable. In each of the analysed types there were seasonal ponds (with the water level less than $20 \mathrm{~cm}$ during inventory works) which tended to go dry in dry years (JUSZCZAK, 2004). Seasonal ponds constitute about $23 \%$ of the water bodies in the catchment and are most numerous among the forest, grassland and field ponds.

Most of the ponds, as many as $83 \%$, were isolated and had neither inlets nor outlets. Only 13 ponds in the Wyskoć catchment had some inlets and 8 of them had both an inlet and an outlet. Only two ponds were connected by ditches which channelled the excess water from the pond to a drainage ditch. Ponds with inlets were the most common among midfield, grassland and wetland reservoirs (4 in each type). Only 3 forest ponds, 2 grassland ones, one farmstead pond and one midfield pond had both inlets and outlets.

In order to find out the reasons of creating new ponds in the Wyskoć catchment the bottom of the reservoir basin and its surroundings were examined in details. Two kinds of reservoirs were distinguished, one group clearly displaying the features of peat ditches, and the other which were former excavations of gravel, sand, or clay. The results indicate that over $48 \%$ of ponds in the Wyskoć catchment were peat ditches which, at least in part, were created as a consequence of purposeful excavation of peat layers and filling the ditches created in this way with ground water. Interestingly, the inventoried peat ditches are the most common not only among grassland ponds (30) and wetland ponds (16), but also among midfield ponds (13). It may indicate the scale of degradation of wetlands in agricultural areas. Probably, wet and peaty hollows were drained and turned into cultivated fields 
some time ago. The evidence for that is provided by ponds located in hollows whose bottom material displays features of peat. About 19\% of ponds were created as a result of gravel, sand or clay excavation after filling the ditches by underground and surface water runoff. Ponds of such features are usually seasonal and go dry in dry seasons since they are usually located on flat area or a hill slope. The remaining 33\% of ponds which were not included in peat ditches or former excavations left after exploitation of mineral fractions were excavated for purposes other than obtaining mineral or peat resources. These are ponds intended for retention, fish farming or recreational purposes.

\section{DISCUSSION}

The results of the inventory of small ponds of an area less than 2 ha carried out in the Wyskoć catchment unambiguously indicate that the number of these ecosystems is increasing. Human impact exerted on these ponds is considered to be intensive (JUSZCZAK and KĘDZIORA, 2003; JUSZCZAK, 2002; 2004), and may lead to the disappearance of some degraded water bodies. However, it should be kept in mind that ponds which were filled-in during the analysed period (1983-2003), were the ones of the area not larger than 100-200 $\mathrm{m}^{2}$ (JUSZCZAK, 2004). So, they were very small. Moreover, these were probably very shallow and seasonal ponds, usually completely overgrown by rush plants. They could have been quite valuable from the natural point of view, their hydrographic value was, however, practically none. How and why were these ponds filled? Unfortunately, only few of the analysed ponds disappeared in a natural way, undergoing the process of natural succession. The majority of ponds were turned into local landfills and sewage discharge ponds (JUSZCZAK, 2004) which were subsequently filled with sand and completely eliminated. Part of midfield ponds were eliminated, being an obstacle to mechanical cultivation of fields and part of farmstead ponds were turned into gardens, farmland, or was designated for a building sites. The fact that no loss of forest and wetland ponds was noted probably indicates that these ponds, due to their location, are one of the most resistant to the processes of quantitative degradation.

From 1980 to 2003, despite the quantitative degradation of ponds, their number in the catchment increased by as much as $16.4 \%$ (in comparison with the present number of existing reservoirs, including the filled ponds). The number of ponds increased at the rate of 4.6 reservoirs (i.e. by $0.7 \%$ ) annually. Unfortunately, the period of analysis was too short to draw conclusions on the long term tendency in the fluctuation of ponds number in the catchment. No analyses were performed on the fluctuation in the number of ponds in the past century or on the dynamics of such changes. It is safe to assume, however, that the number of water bodies decreased in the way and at the rate described in literature (GOŁASKI, 1988; 
KANIECKI, 1991; OlDHAM and SWAN, 1997; PIEŃKOWSKI, 2000). Why then is the number of these ecosystems growing nowadays instead of decreasing, similarly to that in Great Britain? The results of the analyses indicate that in over $70 \%$ of ponds the direct cause of their creation was the exploitation of mineral and peat resources (similarly as it took place in the first half of the 20th century (PIEŃKOWSKI, 2000)). Thus, these ponds were created inadvertently, as by-products of human activity, when the excavations filled with underground and surface water runoffs. Nowadays, however, ponds are created as a result of purposeful actions and are intended for fish farming, recreation or retention of water for agricultural or gardening purposes. It might be assumed that such a tendency in the quantitative change of ponds will be observed also in the future, and the main aim of their creation will be possible economic benefits as well as recreational purposes (passive recreation, fishing, swimming).

It is important to emphasise that the number of all analysed types of ponds is increasing. However, most of them were excavated in grassland and farmland areas which can be crucial for the improvement of the water balance structure of agricultural areas in the Wyskoć catchment. Nevertheless, water bodies included in the above mentioned groups, are not very durable and are the first to be influenced by the processes of quantitative degradation. The increase in the numbers of ponds of longest durability located in wetlands and forests seems to be more beneficial.

Moreover, the replacement of small ponds by much larger ones is an advantageous phenomenon. The average surface of ponds excavated in the analysed period exceeds, at least several times, the average surface of the ponds which were filled in the same time. Having in mind that most of the ponds were located in hollows, it can be claimed that the more such damp hollows are found in the given part of land the more favourable are the conditions for creating new ponds and their number will probably be increasing. The number of farmland and farmstead ponds will be increasing in typically agricultural and plain areas, whereas the number of grassland and wetland ponds will be growing in the areas of different configuration of the landscape.

A disturbing phenomenon is that most (as many as 83\%) of ponds have no outflows. Such reservoirs are usually located in non-outflow local hollows and retain water which flows from the higher areas. Such a situation might be dangerous because of rapidly proceeding pollution of the water in such ponds with eutrophic runoff from neighbouring farmland areas (JUSZCZAK, 2004). These water bodies will undergo advancing processes of natural succession which in several years may lead to their becoming completely shallow and overgrown with macrophytes. Another problem seems to be the fact that the analysed ponds are dispersed and thus it is difficult to connect them with a network of drainage ditches. Only 23 water bodies were included into more or less effective systems of drainage ditches on which the systems of gates can be built. Thereby, the importance of ponds as small water 
retention reservoirs for irrigation purposes is and will remain little, since only connecting the dispersed ponds with the system of draining ditches can ensure the effective management of retained water (KosTURKIEWICZ and FIEDLER, 1995; KosTURKIEWICZ et al., 2001). Such activities would be all the more justified, as, according to our study, over $8 \%$ of the inventoried ponds did not retain water in summer time and other $23 \%$ of water bodies tended to run dry in dry years. Most of the ponds of such properties were located in flat areas or in very shallow hollows. It means that in order to create ponds which will constantly preserve the water level we should locate them in damp hollows retaining water from surface and undersurface runoffs.

\section{CONCLUSIONS}

1. The number of ponds (with the area less than 2 ha) in the Wyskoc catchment was increasing in the analysed period, from 1980 to 2003, at the rate of about 4.6 water bodies per year, while small ponds are being replaced by those having a larger surface. Assuming the described tendency in the fluctuations of the number of small ponds is fixed, we might assume that the number of ponds in the Wyskoc catchment will be increasing.

2. The direct cause of creation of over $70 \%$ newly excavated water bodies was the exploitation of mineral and peat resources and filling holes and excavations remaining after peat, gravel, sand or clay exploitation with water from surface and subsurface runoff. Thus, these ponds came into existence as a by-product of human activity. Nowadays, however, ponds are more often created as a result of intentional human activities and are designed for fish farming, recreation and as water retention reservoirs used in irrigation of small agricultural and gardening areas.

3. Increasing interest in the possibility of application of small ponds for agricultural or recreational purposes may be the factor which will contribute to the increase of the number of water bodies in the surrounding landscape within the next several years.

\section{REFERENCES}

1. Biggs J., Fox G., Nicolet P., Walker D., Whitfield M., Williams P., 1998. A guide to the methods of the National Pond Survey. Oxford, Pond Action: 22.

2. Biggs J., Williams P., Barr C., Cummins C., Gillespies M., Rich T., Baker A., Baker J., Beesley J., Corfield A., Dobson D., Culling A., Fox G., Howard D., Luursema K., Rich M., SAmson D., SCOtT A., White R., Whitfield M., 2000. The ecological quality of ponds in Britain the results of the DETR Lowland Pond Survey. In: Proceedings of the Pond Conference 1998. Oxford, Pond Action: 18-22. 
3. Bischoff N.T., Jongman R.H.G., 1993. Development of rural areas in Europe: the claim for nature. Netherlands Scientific Council for Government Policy. The Hage: 206.

4. BRIERS R., BIGGS J., 2003. Indicator taxa for conservation of pond invertebrate diversity. Aquatic Conservation: Marine and Freshwater Ecosystems 13: 323-330.

5. BÜLOW-OlSEN A., 1988. Disappearance of ponds and lakes in southern Jutland, Denmark 1954 -1984. Ecol. Bull. 39: 180-182.

6. Collinson N.H., Biggs J., Corfield A., Hodson M.J., Walker D., Whitfield M., Williams P.J., 1995. Temporary and permanent ponds: an assessment of the effects of drying out on the conservation value of aquatic macroinvertebrate communities. Biological Conservation 74: 125-133.

7. Fiedler M., SZAFrańSKi CZ., 1999. Variation of ground-water levels in the catchment of the midfield pond located at Gniezno Lakeland. Rocz. AR Poznań 20: 403-412.

8. FIEDler M., SzAFraŃSKi CZ., BYKOWSKI J., 2002. Zasoby wodne mikrozlewni rolniczej z występującymi oczkami wodnymi. (Water resources of agricultural micro-catchment with small ponds). Rocz. AR Poznań 23: 73-81.

9. Fleischer S., Gustafson S., Jooelsson S., PAnSAR S., Stibe S., 1994. Nitrogen removal in created ponds. Ambio, 23: 349-357.

10. GOŁASKi J., 1988. Atlas rozmieszczenia młynów wodnych w dorzeczach Warty, Brdy i części Baryczy w okresie 1790 do 1960. Cz. 1. Środkowa Warta, Prosna i Barycz. (Atlas of location of small water mills in the river basins of the Warta, Brda and part of the Barycza in the period from 1790 to 1960. Chapter 1. The middle Warta, Prosna and Barycz). Poznań, Wydaw. AR.

11. Gustafson A., Fleischer S., JoelsSON A., 1988. Decreased leaching and increased retention potential co-operaive measures to reduce diffuse nitrogen load on a watershed level. Wat. Sci. Techn. 38, 10: 181-189.

12. Gustafson A., Fleischer S., JoelsSON A., 2000. A catchment-oriented and cost-effective policy for water protection. Ecol. Engin. 14: 419-427.

13. HubBARD D.H., Linder., 1986. Spring off retention in prairie pothole wetlands. J. Soil Water Conservation 41: 122-125.

14. Hull A., 1997. The pond life project: a model for conservation and sustainability. In: British Pond Landscape. Ed. J. Boothby. Proceedings from the UK conference of the Pond Life Project. Liverpool, Pond Life Project: 101-109.

15. JUSZCZAK R., 2002. Zagrożenia, degradacja i ochrona małych zbiorników wodnych w zlewni Rowu Wyskoć. (The threats, degradation and protection of small water reservoirs in the Wyskoć catchment). Rocz. AR Poznań 23: 159-170.

16. JusZCZAK R., KęDZIORA A., 2003 Threats to and deterioration of small water reservoirs located within Wyskoć catchment. Polish J. Environ. Stud. 12, 5: 567-573.

17. JUSZCZAK R., 2004. Inwentaryzacja i waloryzacja małych zbiorników wodnych w zlewni Rowu Wyskoć. (Inventory and evaluation of small water reservoirs in the Wyskoć catchment, $\mathrm{PhD}$ thesis, manuscript). Poznań, AR, Katedry Agrometeorologii pr. doktorska, maszyn.: 194.

18. KalettKA T., 1996. Die Problematik der Soelle (Kleinhohlformen) im Jungemoraenengebiet Nordostdeutschland. Naturschutz u. Landschftsplege in Brandenburg, Sonderheft ,Soelle“: 4-12.

19. KANIECKI A., 1991. Problem odwodnienia Niziny Wielkopolskiej w ciagu ostatnich 200 lat i zmiany stosunków wodnych. Ochrona i racjonalne wykorzystanie zasobów wodnych na obszarach rolniczych w regionie Wielkopolski. W: Ochrona i racjonalne wykorzystanie zasobów wodnych na obszarach rolniczych w Wielkopolsce. (Dehydration problem of the Wielkopolska Lowland in the last 200 years and changes of water regimes. In: Protection and rational use of water resources in agricultural areas of Wielkopolska). Red. A. Kosturkiewicz. ODR Sielinko, Poznań: 73-80.

20. KEEN D., 2000. The paleology of ponds: evidence from the Pleistocene record. In: Proceedings of the Pond Conference 1998. Pond Action, Oxford: 5-9.

21. KONDRACKI J., 1998. Geografia regionalna. (The regional geography). Warszawa, Wyd. PWN: 440.

22. Koskiaho J., Ekholm P., Raty M., Rimimaki J., Puustinen M., 2003. Retaining agricultural nutrients in constructed wetlands - experiences under boreal conditions. Ecol. Eng. 20: 89-103. 
23. Kosturkiewicz A., Fiedler M., 1995. Oczka wodne w eksploatacji systemów drenarskich na terenach bogato urzeźbionych. (Small ponds in exploitation of drainage systems in the hilly area). Zesz. Nauk. AR Wrocław 266: 191-199.

24. Kosturkiewicz A., FiedLer M., 1996. Retencja odpływów drenarskich w bilansie wodnym śródpolnego oczka wodnego i jakość retencjonowanych wód. (Retention of drainage outflows in the water balance of midfield pond and the quality of retained water). Zesz. Nauk. AR Wroc. 289: 83-91.

25. Kosturkiewicz A., SZAFraŃKi CZ., CZOPOR S., Korytowski M., Stasik R., 2001. Związki stanów wód $\mathrm{w}$ śródleśnych oczkach wodnych ze stanami wód gruntowych $\mathrm{w}$ przyległych siedliskach leśnych. W: Funkcjonowanie geoekosystemów w zróżnicowanych warunkach morfoklimatycznych - monitoring, ochrona, edukacja. (Relationships between water level in the forest ponds and ground water level in the surroundings areas. In: Functioning of geoecosystems in varible morpho-climatic conditions - monitoring, protection, education). Red. A. Karczewski, Z. Zwoliński. Poznań, Stow. Geomorf. Pol.: 237-250.

26. Kosturkiewicz A., SzAFrański Cz., Korytowski M., Stasik R., 2002. Bilanse wodne śródleśnych oczek wodnych. (Water balances of forest ponds). Czas. Tech. Inż. Środ. 8: 63-71.

27. Nicolet P., 2000. 25 years of change in the plant communities and conservation value of some Cheshire ponds. Proc. Ponds. Conf. Pond Action, Oxford: 49-55.

28. Oertli B., Joye D.A., Castella E., Juge R., Cambin D., Lachavanne J.B., 2002. Does size matter? The relationship between pond area and biodiversity. Biol. Conserv. 104: 59-70.

29. Oldham R.S., Swan M.J.S., 1997. Pond loss and amphibians: Historical Perspectives. In: British Pond Landscape: Proc. UK Conf. Pond Life Project, 7-9 September 1997.

30. PIEŃKOWSKi P., 2000. Disappearance of ponds in the younger Pleistocene landscape of Pomerania. J. Water Land Develop., 4: 55-68.

31. RingLeR A. 1976. Verlustibilanz Nasser Kleinbiotope in Moraenengebieten der Bundesrepublik Deutschland. Natur und Landschaft 51, 7/8: 205-209.

32. RYSZKOWSKI L., ŻYCZYŃSKA-BAŁONIAK I., SZPAKOWSKA B., 1996. Wpływ barier biogeochemicznych na rozprzestrzenianie się zanieczyszczeń obszarowych. W: Oczyszczalnie hydrobotaniczne. (Influence of biogeochemical barriers on spreading of non-point pollution. In: Hydrobotanic sewage treatment plants). 2. Międzyn. Konf. Nauk.-Tech. Poznań: 147-156.

33. RYSZKOWSKI L., ŻYCZYŃSKA-BAŁONIAK I., 1998. Ograniczenie zanieczyszczeń obszarowych przez bariery biogeochemiczne. W: Kształtowanie środowiska rolniczego na przykładzie Parku Krajobrazowego im. Gen. D. Chłapowskiego. (Limitation of aerial pollutions by biogeochemical barriers. In: Management of agricultural environment - an example of Gen. D. Chłapowski Landscape Park). Red. L. Ryszkowski, S. Bałazy. Poznań, PAN: 67-80.

34. Smith S.V., ReNwick W.H., BARTLey J.D., BudDEMEIER R.W., 2002. Distribution and significance of small, artificial water bodies across the United States landscape. Sci. Total Envir. 299: 21-36.

35. Swan M.J.S., Oldham R.S., 1989. Amphibian communities. Final Report. Nature Conserv. Council, Peterborough.

36. Williams P.J., Biggs J., Barr C.J., Cummins C.P., Gillespie M.K., Rich T.C.G., Baker A., Baker J., Beesley J., Corfield A., Dobson D., Culling A.S., Fox G., Howard D.C., LuUrsema K., Rich M., Samson D., Scott W.A., White R., Whitfield M., 1998. Lowland Pond Survey 1996. Department of the Environment, Transport and the Regions, London.

37. Williams P., Biggs J., Whitfield M., Thorne A., Bryant S. Fox G., Nicolet P., 1999. The Pond Book: A Guide to the Management and Creation of Ponds. Ponds Conservation Trust, Oxford: 105.

38. Williams P., Biggs J., Whitfield M., Fox G., Nicolet P., 2000. Ancient ponds and modern landscapes. Proc. Ponds Conf. 1998, Pond Action, Oxford: 10-17.

39. Williams P., Whitfield M., Biggs J., Bray S., Fox G., Nicolet P., Sear D., 2004. Comparative biodiversity of rivers, streams, ditches and ponds in an agricultural landscape in Southern England. Biological Conservation, 115, 2: 329-341.

40. ŻYCZYŃSKA-BAŁONIAK I., JASKULSKA R., SZYMAŃSKI R., 1990. Niektóre składniki chemiczne rozpuszczone w wodzie małych zbiorników śródpolnych. W: Charakterystyki ekologiczne wybra- 
nych elementów krajobrazów rolniczych. (Some chemical components dissolved in water of small midfield ponds. In: Ecologic characteristics of selected elements of agricultural landscapes). Warszawa, SGGW-AR: 62-77.

\section{STRESZCZENIE}

\section{Zmiana liczby małych zbiorników wodnych na obszarze zlewni Rowu Wyskoć w latach 1980-2003 i charakterystyka nowo wykopanych zbiorników wodnych}

Słowa kluczowe: mate zbiorniki wodne, presja antropogeniczna, zmiana liczby zbiorników wodnych

W artykule przedstawiono wyniki analiz zmian liczby małych zbiorników wodnych na obszarze zlewni Rowu Wyskoć w latach 1980-2003 oraz wybrane charakterystyki zbiorników wodnych wykopanych w tym okresie. Analizie poddano wyłącznie zbiorniki małe o powierzchniach poniżej 2 ha. Wszelkie analizy wykonywano na podstawie map topograficznych w skali 1:10 000 oraz zdjęć lotniczych z $1996 \mathrm{r}$.

Uzyskane wyniki jednoznacznie wskazują, że liczba małych zbiorników wodnych w zlewni Rowu Wyskoć zwiększa się. Jest to szczególnie widoczne w przypadku zbiorników zlokalizowanych na polach uprawnych i użytkach zielonych. W znacznie mniejszym stopniu zwiększyła się liczba zbiorników śródleśnych oraz zbiorników zlokalizowanych na mokradłach. W analizowanym okresie nie zasypano ani jednego zbiornika zlokalizowanego w lesie bądź na terenie podmokłym, tak więc stwierdzić można, że zbiorniki zlokalizowane na tych użytkach są najbardziej odporne na procesy degradacji ilościowej. Bezpośrednią przyczyną wykopania około $70 \%$ zbiorników wodnych była eksploatacja surowców mineralnych (żwiru, pospółki, gliny), bądź torfu. Obecnie jednak, małe zbiorniki wodne są coraz częściej tworzone w wyniku celowych działań, jako zbiorniki przeznaczone do hodowli ryb, wędkarstwa, rekreacji, lub jako zbiorniki retencyjne wód wykorzystywanych do małoobszarowych nawodnień rolniczych i ogrodniczych.

Reviewers:

Received 09.10.2006

Prof. Waldemar Mioduszewski

Prof. Czesław Szafrański 